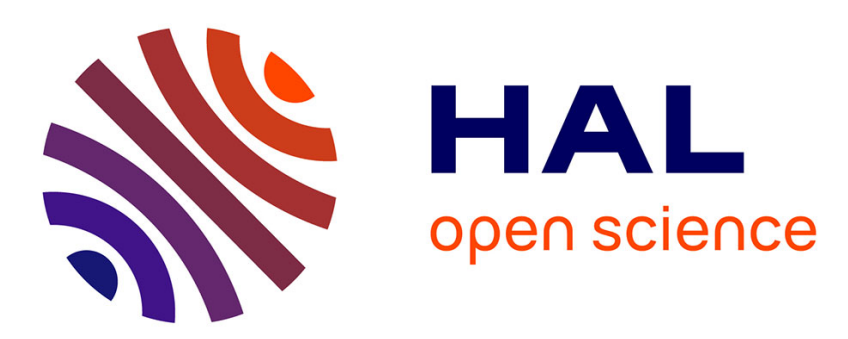

\title{
Biogenic silica dissolution in diatom aggregates: Insights from reactive transport modelling
}

Brivaëla Moriceau, Goulven G. Laruelle, Uta Passow, Philippe van Cappellen, Olivier Ragueneau

\section{- To cite this version:}

Brivaëla Moriceau, Goulven G. Laruelle, Uta Passow, Philippe van Cappellen, Olivier Ragueneau. Biogenic silica dissolution in diatom aggregates: Insights from reactive transport modelling. Marine Ecology Progress Series, 2014, 517, pp.35-49. 10.3354/meps11028 . hal-01083569

\section{HAL Id: hal-01083569 https://hal.science/hal-01083569}

Submitted on 21 Apr 2020

HAL is a multi-disciplinary open access archive for the deposit and dissemination of scientific research documents, whether they are published or not. The documents may come from teaching and research institutions in France or abroad, or from public or private research centers.
L'archive ouverte pluridisciplinaire HAL, est destinée au dépôt et à la diffusion de documents scientifiques de niveau recherche, publiés ou non, émanant des établissements d'enseignement et de recherche français ou étrangers, des laboratoires publics ou privés. 


\title{
Biogenic silica dissolution in diatom aggregates: insights from reactive transport modelling
}

\author{
Brivaëla Moriceau ${ }^{1, *}$, Goulven Gildas Laruelle ${ }^{2,3}$, Uta Passow ${ }^{4}$, \\ Philippe Van Cappellen ${ }^{5}$, Olivier Ragueneau ${ }^{1}$ \\ ${ }^{1}$ Laboratoire des Sciences de l'Environnement Marin, UMR 6539 CNRS/UBO/IRD, IUEM, Technopôle Brest-Iroise, \\ 4 rue Dumont d'Urville, 29280 Plouzané, France \\ ${ }^{2}$ Faculty of Geosciences, Department of Earth Sciences - Geochemistry, Utrecht University, PO Box 80021, 3508 TA Utrecht, \\ The Netherlands \\ ${ }^{3}$ Biogeochemical Modelling of the Earth System, Dépt. des Sciences de la Terre et de l'Environnement, \\ Université Libre de Bruxelles, 1050 Bruxelles, Belgium \\ ${ }^{4}$ Marine Science Institute, University of California Santa Barbara, CA 93106, USA \\ ${ }^{5}$ Department of Earth and Environmental Sciences, University of Waterloo, Waterloo, ON N2L 3G1, Canada
}

\begin{abstract}
Diatom aggregates contribute significantly to the vertical sinking flux of particulate matter in the ocean. These fragile structures form a specific microhabitat for the aggregated cells, but their internal chemical and physical characteristics remain largely unknown. Studies on the impact of aggregation on the Si cycle led to apparent inconsistency. Despite a lower biogenic silica $\left(\mathrm{bSiO}_{2}\right)$ dissolution rate and diffusion of the silicic acid ( $\mathrm{dSi}$ ) being similar in aggregates and in seawater, dSi surprisingly accumulates in aggregates. A reaction-diffusion model helps to clarify this incoherence by reconstructing $\mathrm{dSi}$ accumulation measured during batch experiments with aggregated and non-aggregated Skeletonema marinoi and Chaetoceros decipiens. The model calculates the effective $\mathrm{bSiO}_{2}$ dissolution rate as opposed to the experimental apparent $\mathrm{bSiO}_{2}$ dissolution rate, which is the results of the effective dissolution of $\mathrm{bSiO}_{2}$ and transport of $\mathrm{dSi}$ out of the aggregate. In the model, dSi transport out of the aggregate is modulated by alternatively considering retention (decrease of the dSi diffusion constant) and adsorption (reversible chemical bonds between dSi and the aggregate matrix) processes. Modelled $\mathrm{bSiO}_{2}$ dissolution is modulated by the impact of dSi concentration inside aggregates and diatom viability, as enhanced persistence of metabolically active diatoms has been observed in aggregates. Adsorption better explains dSi accumulation within and outside aggregates, raising the possible importance of dSi travelling within aggregates to the deep sea (potentially representing $20 \%$ of the total silica flux). The model indicates that $\mathrm{bSiO}_{2}$ dissolution is effectively decreased in aggregates mainly due to higher diatom viability but also to other parameters discussed herein.
\end{abstract}

KEY WORDS: Silicic acid $\cdot \mathrm{dSi}$ accumulation $\cdot \mathrm{dSi}$ diffusion $\cdot \mathrm{dSi}$ adsorption · Transparent exopolymer particles $\cdot$ TEP $\cdot$ Viability $\cdot$ Si cycle

\section{INTRODUCTION}

Diatoms are an important phytoplankton group for the study of biogeochemical cycles, linking carbon and silica cycles through their particular metabolism. With a share of $40 \%$ on average of the global oceanic primary production and up to $75 \%$ in nutrient-rich areas (Nelson et al. 1995, Tréguer et al. 1995, Mann 1999, Booth et al. 2002, Tréguer \& De La Rocha 2013), diatoms contribute appreciably to carbon export (Nelson et al. 1995, Tréguer et al. 1995, Buesseler 1998, Ragueneau et al. 2006). This statement is supported by strong correlations observed at depth between silica and organic carbon sinking fluxes (Arm- 
strong et al. 2002, 2009, Ragueneau et al. 2006). Considering that export results from the equilibrium between sedimentation and remineralisation rates, a single cell has almost no chance of escaping dissolution and degradation in the euphotic zone (Moriceau et al. 2007a), except for some large deep-dwelling diatoms (Kemp et al. 2006). However, as components of aggregates or faecal pellets, diatoms can be exported to the deep layers of the ocean and to the sediment floor in only few days, as shown by direct observations of diatomaceous phytodetritus at the sea floor (Billett et al. 1983, Kemp et al. 2000). Aggregates and faecal pellets are indeed the main contributors to the sedimentation fluxes (Thornton 2002, Turner 2002, Guidi et al. 2009, Iversen \& Ploug 2010, Stemmann \& Boss 2012).

The aggregation process promotes the export of silica not only through an increase in the sedimentation rate, but also through a decrease in biogenic silica $\left(\mathrm{bSiO}_{2}\right)$ dissolution rates (Passow et al. 2003, Moriceau et al. 2007b). Moreover, while aggregates efficiently export particulate matter, these particles also transport the dissolved matter trapped within their porewater (De La Rocha et al. 2008). Roughly $20 \%$ of nitrogen and carbon fluxes are transported in their soluble forms inside aggregates (Carlson et al. 1994, 1998, Williams 1995, Hansell \& Carlson 1998, Engel et al. 2004, Hopkinson \& Vallino 2005). To our knowledge, similar estimates have not yet been made for silicic acid. Concentrations of silicic acid, $\mathrm{dSi}$, within diatom aggregate porewater could be 4 to 50 times higher than the environmental dSi concentrations (Brzezinski et al. 1997, Moriceau et al. 2007b). On the other hand, estimates of dSi diffusion out of aggregates based on direct determinations of oxygen diffusivity within aggregates suggest that diffusion is only slightly reduced in aggregates, with values approaching $90 \%$ of free diffusion in seawater (Ploug \& Passow 2007). These 2 results could be easily explained considering a very fast $\mathrm{bSiO}_{2}$ dissolution within aggregates to compensate for the diffusion of dSi out of aggregates as hypothesized by Brzezinski et al. (1997). Moreover, this hypothesis would be supported by the bacterial community found on marine aggregates (DeLong et al. 1993) together with the high bacterial degradation measured in marine aggregates (Smith et al. 1992, Iversen \& Ploug 2010) that is generally associated with high $\mathrm{bSiO}_{2}$ dissolution rates (Bidle \& Azam 1999, Tamburini et al. 2006). However, direct measurements of silica dissolution have invalidated this hypothesis, as dissolution rates even lower than in freely suspended diatoms have been measured for aggregated diatom cells (Passow et al. 2003, 2011, Moriceau et al. 2007b). This raises the question of how such high dSi concentrations can occur inside aggregates while dSi diffusion extrapolated from oxygen diffusion is similar to diffusion in seawater and $\mathrm{bSiO}_{2}$ dissolution is lower in aggregates. In laboratory experiments, dissolution rates for aggregated diatoms are derived from the kinetics of the dSi concentration increase outside the aggregates. The net dissolution rates measured from the build-up of dSi outside the aggregates are apparent silica dissolution rates resulting from both the effective dissolution rate of frustules inside the aggregates and the transport of the newly generated $\mathrm{dSi}$ out of the aggregates. The only way to separate the effects of dissolution kinetics and intra-aggregate transport is to use a reaction-transport model to calculate the effective $\mathrm{bSiO}_{2}$ dissolution rates of aggregated diatoms while reconstructing the accumulation of $\mathrm{dSi}$ inside the aggregates. We therefore conducted 2 sets of modelling experiments to test the implications of alternative mechanisms of transport and dissolution within diatom aggregates.

The first set of model simulations sought to understand transport of dSi inside an aggregate. The accumulation of dSi within aggregates was modelled alternatively using adsorption and retention processes to slow down dSi transport within aggregates. The goodness of fit to experimental dSi concentrations measured outside and inside the aggregates was used to choose between these 2 processes. In our study, 'retention' refers to processes possibly slowing down dSi transport without involving chemical binding as in Van der Waals interactions, polarity or size of silicic acid molecules, and fractal dimensions of the aggregates. In contrast, the term 'adsorption' includes all reversible processes involving chemical binding of $\mathrm{dSi}$ to the aggregate matrix.

The second modelling experiment estimated the relative contribution of 2 parameters identified and measured during an earlier experimental study (Moriceau et al. 2007b) to change the effective dissolution rates of aggregated diatoms compared to their free counterparts. The 2 identified processes are (1) the elevated $\mathrm{dSi}$ concentrations inside aggregates that reduce the thermodynamic driving force for $\mathrm{bSiO}_{2}$ dissolution and, hence, the effective dissolution rate (Van Cappellen \& Qiu 1997), and (2) the diatom cells maintaining a higher ratio of metabolically active cells (hereafter called viability) in the aggregates than when freely suspended in seawater. Metabolically active cells tend to inhibit the dissolution of their frustules, hence again leading to lower effective silica dissolution rates for aggregated diatoms (Nelson et al. 1976, Passow et al. 2011). 
The model simulates $\mathrm{bSiO}_{2}$ dissolution of diatom frustules within an aggregate. Parameterization is based on data from in vitro dissolution experiments conducted with Skeletonema marinoi and Chaetoceros decipiens (Moriceau et al. 2007b). The model calculates effective dissolution rates for the various scenarios considered as well as the net flux of silicic acid out of the aggregates. Using this flux, the model derived the temporal evolution of internal and external dSi concentrations. Together with the average internal dSi concentration, the latter can be compared to the dSi concentrations measured experimentally.

\section{METHODS}

\section{Model description \\ General description}

In the model, an aggregate is represented as a porous sphere of radius $r_{\text {agg }}$ composed of biogenic silica $\left(\mathrm{bSiO}_{2}\right)$ embedded in a gel-like matrix of transparent exopolymer particles (TEP). Most of the aggregate's volume is occupied by seawater, through which dSi diffuses. The constant porosity $\phi$ of 0.95 (Table 1) imposed in the aggregate model accounts for the volume contributions of diatom cells (1\% in Moriceau et al. 2007b) and TEP (4\% in Passow 2002). Using an equation from a study by Nielsen (1984), and the median value for excess density of marine snow aggregates $\Delta \rho=1.4 \times 10^{-4} \mathrm{~g}$ $\mathrm{cm}^{-3}$ presented by Alldredge \& Gotschalk (1988), the diffusion layer thickness $\delta$ was estimated at $0.01 \mathrm{~cm}$, which is typical for many mass transfer problems (Cussler 1984). Ploug \& Jørgensen (1999) and Boudreau \& Jørgensen (2001) reported values between 0.04 and $0.08 \mathrm{~cm}$ by measuring oxygen distributions around an aggregate of similar size as the diatom aggregates used herein (see Table 1) sinking freely through seawater at $60 \mathrm{~m} \mathrm{~d}^{-1}$. At higher flow velocities as generally measured in aggregates made in roller tanks (Iversen \& Ploug 2010, Ploug et al. 2010), the relative flow velocity increases and $\delta$ decreases. The concentration difference of the dSi in the aggregate and its boundary layer approximated using Fick's law should not exceed $10^{-1} \mu \mathrm{M}$. This value was obtained from a flux of silicic acid across the boundary layer of 1.13 $\times 10^{-4} \mathrm{nmol} \mathrm{cm}^{-2} \mathrm{~s}^{-1}$ calculated with Eq. (1):

$$
J=\left(V_{\text {agg }} \cdot \mathrm{bSiO}_{2} \cdot \mathrm{MW}_{\mathrm{bSiO} 2} \cdot \mathrm{Ra}_{\text {dis }}\right) / \mathrm{SA}_{\text {agg }}
$$

Table 1. Parameters used in the model with the parameterization and initial conditions chosen from the experiment described by Moriceau et al. (2007b) and from the literature. dSi: silicic acid; SM: Skeletonema marinoi; CD: Chaetoceros decipiens; conc.: concentration; NM: not measurable. Subscript agg: aggregate; aq: aqueous

\begin{tabular}{|c|c|c|c|}
\hline & Abbreviation & Value & Units \\
\hline \multicolumn{4}{|l|}{ Parameter } \\
\hline Molecular weight & $\mathrm{MW}_{\mathrm{bSiO} 2}$ & 66 & $\mathrm{~g} \mathrm{~mol}-1$ \\
\hline Porosity ${ }^{\mathrm{a}}$ & $\phi$ & 0.95 & $\mathrm{~cm}^{3}{ }_{\text {aq }} \mathrm{cm}^{-3}$ agg \\
\hline Diffusion constant ${ }^{\mathrm{b}}$ & $D$ & $0.80 \times 10^{-5}$ & $\mathrm{~cm}^{2} \mathrm{~s}^{-1}$ \\
\hline dSi solubility ${ }^{\mathrm{c}}$ & $\mathrm{dSi}_{\mathrm{eq}}$ & 1500 & $\mu \mathrm{M}\left(\mu \mathrm{mol} \mathrm{l}^{-1}\right)$ \\
\hline $\begin{array}{l}\text { Final average dSi co } \\
\text { in an aggregate }\end{array}$ & nc. $\overline{\mathrm{dSi}} \overline{a g g}$ & 80 & $\mu \mathrm{M}\left(\mu \mathrm{mol} \mathrm{l} \mathrm{l}^{-1}\right)$ \\
\hline \multicolumn{4}{|l|}{ Viability } \\
\hline $\begin{array}{l}\mathrm{SM} \\
\mathrm{CD}\end{array}$ & $f_{\text {viab }}$ & $\begin{array}{l}\text { NM } \\
0.50\end{array}$ & \\
\hline \multicolumn{4}{|l|}{ Aggregate radius } \\
\hline $\begin{array}{l}\text { SM } \\
\text { CD }\end{array}$ & $r_{\text {agg }}$ & $\begin{array}{c}0.375 \\
0.3\end{array}$ & $\mathrm{~cm}$ \\
\hline \multicolumn{4}{|c|}{ Volume of seawater per aggregate } \\
\hline $\begin{array}{l}\mathrm{SM} \\
\mathrm{CD}\end{array}$ & $V$ & $\begin{array}{c}10 \\
12.5\end{array}$ & $\mathrm{~cm}^{3}$ \\
\hline \multicolumn{4}{|c|}{ Initial conditions (experimental data) } \\
\hline $\begin{array}{l}\text { External dSi conc. } \\
\text { SM } \\
\text { CD }\end{array}$ & $\mathrm{dSi}_{\text {ext }}$ & $\begin{array}{l}6 \\
9\end{array}$ & $\mu \mathrm{M}\left(\mu \mathrm{mol} \mathrm{l}{ }^{-1}\right)$ \\
\hline $\begin{array}{l}\text { Internal } \mathrm{bSiO}_{2} \text { conc. } \\
\quad \mathrm{SM} \\
\text { CD }\end{array}$ & $\mathrm{bSiO}_{2}$ & $\begin{array}{l}1.41 \\
3.8\end{array}$ & mmol l-1 agg \\
\hline \multicolumn{4}{|c|}{ 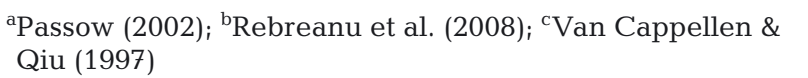 } \\
\hline
\end{tabular}

where $V_{\text {agg }}$ and $\mathrm{SA}_{\text {agg }}$ are the volume and the surface area of the aggregate, respectively; $\mathrm{bSiO}_{2}$ is the biogenic silica concentration in the aggregate, $\mathrm{MW}_{\mathrm{bSiO} 2}$ is the molecular weight of the biogenic silica, and $\mathrm{Ra}_{\text {dis }}$ is the apparent dissolution rate constant of the biogenic silica.

We hypothesized that a diffusive layer of $0.01 \mathrm{~cm}$ with a dSi concentration of $10^{-1} \mu \mathrm{M}$ would not change the results of the model. Consequently, the diffusive layer was not taken into account in this model.

Spatial and temporal changes in the silicic acid concentration inside the aggregate $\left(\mathrm{dSi}_{\text {agg }}\right)$ are calculated assuming spherical symmetry and molecular diffusion as the only solute transport mechanism:

$$
\frac{\partial \mathrm{dSi}_{\mathrm{agg}}}{\partial t}=\frac{1}{r^{2}} \cdot \frac{\partial}{\partial r}\left(r^{2} \cdot D_{\text {eff }} \cdot \frac{\partial \mathrm{dSi}_{\mathrm{agg}}}{\partial r}\right)+R_{\mathrm{dSi}}
$$

where $t$ is time, $r$ is the radial distance from the centre of the aggregate, with a maximum value of $r_{\text {agg }}$ being the radius of the aggregate, $D_{\text {eff }}$ is the effective diffusion constant, and $R_{\mathrm{dSi}}$ is the net rate of 
production of $\mathrm{dSi}$ in the aggregate or the effective $\mathrm{bSiO}_{2}$ dissolution rate.

The effective diffusion constant used to model dSi transport inside aggregates, $D_{\text {eff }}$ is calculated using the molecular diffusion constant of $\mathrm{dSi}, D$. $D$ is proportional to the rate at which dSi molecules are transported from a more concentrated medium to a less concentrated one. $D$ has been measured in seawater at $15^{\circ} \mathrm{C}$ by Rebreanu et al. (2008). To adapt the dSi diffusion constant, $D$, measured in seawater to the aggregate porewater, $D$ is corrected using Eq. (3) for the tortuosity of the aggregate, which is a function of the aggregate porosity $\phi$ (Boudreau 1997):

$$
D_{\mathrm{dSi}}=D /\left(1-\ln \left(\phi^{2}\right)\right)
$$

Given that aggregate particles are fractal, diatom cells are assumed to be homogeneously distributed inside the aggregate. We further assumed that no $\mathrm{bSiO}_{2}$ production took place in the aggregates, as the experiments were conducted in the dark (Peters \& Thomas 1996), hence mimicking aggregates sinking rapidly out of the euphotic zone.

\section{Variations including retention or adsorption}

In the retention version, we introduce a retention factor $f_{\text {ret }}$ equal to or greater than 1 :

$$
D_{\text {eff }}=D_{\mathrm{dSi}} / f_{\text {ret }}
$$

In this version of the model, $R_{\mathrm{dSi}}$ of Eq. (2) is expressed as follows:

$$
\begin{aligned}
R_{\mathrm{dSi}}= & \frac{1}{\phi} \cdot k_{\mathrm{dis}} \cdot \mathrm{bSiO}_{2} \cdot\left(\mathrm{MW}_{\mathrm{bSiO} 2} \cdot 10^{-6}\right) . \\
& \left(1-f_{\text {viab }}\right) \cdot\left(1-\frac{\overline{\mathrm{dSi}_{\text {agg }}}}{\mathrm{dSi}_{\text {eq }}}\right)^{m}
\end{aligned}
$$

where $k_{\text {dis }}$ is the mass-normalized dissolution rate constant of $\mathrm{bSiO}_{2}, \mathrm{MW}_{\mathrm{bSiO} 2}$ is the molecular weight of $\mathrm{bSiO}_{2}, f_{\text {viab }}$ is the fraction of metabolically active diatoms, $\mathrm{dSi}_{\text {eq }}$ is the equilibrium solubility of $\mathrm{bSiO}_{2}$ at $15^{\circ} \mathrm{C}$ (Table 1). Note that the dependency of $R_{\mathrm{dSi}}$ with the undersaturation degree

$$
\left(1-\frac{\overline{\mathrm{dSi}_{\text {agg }}}}{\mathrm{dSi}_{\text {eq }}}\right)
$$

can be strongly non-linear at low dSi concentrations which could be expressed using a value of $m>1$, where $m$ is the non-linearity parameter. With $m=1$, the relation becomes the so-called linear rate law, which is frequently used to describe the dissolution of $\mathrm{bSiO}_{2}$ (Van Cappellen et al. 2002) and will be used in this study considering the high silicic acid concentrations measured experimentally in aggregates (Shanks \& Trent 1979, Brzezinski et al. 1997, Moriceau et al. 2007b). Eq. (5) assumes that diatom cells must be dead in order for their frustules to dissolve (Nelson et al. 1976, Passow et al. 2011). During a model run, the value of $f_{\text {viab }}$ remains constant, as no measurable change in the ratio of active diatoms was detected for up to $480 \mathrm{~h}$ in a study with Thalassiosira weissflogii aggregates (Garvey et al. 2007).

In the 'adsorption' version of the model, we hypothesized that high dSi concentrations inside aggregates are due to adsorption of $\mathrm{dSi}$ to the aggregate matrix. When adsorption occurs, 2 pools of soluble silica coexist within the aggregates, i.e. the free $\mathrm{dSi}$, which is freely diffusing through the aggregate porewater, and the adsorbed $\mathrm{dSi}$, which is reversibly bound to the aggregate matrix. Therefore, the model considers 3 pools of dSi: (1) the external dSi $\left(\mathrm{dSi}_{\text {ext }}\right)$ in the seawater surrounding the aggregate, (2) the adsorbed $\mathrm{dSi}\left(\mathrm{dSi}_{\mathrm{ads}}\right)$ inside the aggregate and (3) the free $\mathrm{dSi}$ $\left(\mathrm{dSi}_{\text {free }}\right)$ in the aggregate. The $3 \mathrm{dSi}$ pools are linked to each other through the adsorption equilibrium between $\mathrm{dSi}_{\text {free }}$ and $\mathrm{dSi}_{\mathrm{ads}}$ and through the diffusion of $\mathrm{dSi}_{\text {free }}$ out of the aggregate:

$$
\mathrm{dSi}_{\text {ads }} \stackrel{k_{\text {ads }}}{\longleftrightarrow} \mathrm{dSi}_{\text {free }} \stackrel{\text { Deff }}{\longrightarrow} \mathrm{dSi}_{\text {ext }}
$$

At any point in time and space, the free and adsorbed $\mathrm{dSi}$ in the aggregate are assumed to be in equilibrium. We further assume that the 2 concentrations are related by a simple linear isotherm (Berner 1980) through the dSi linear adsorption constant $k_{\text {ads }}$ :

$$
\mathrm{dSi}_{\text {ads }}=k_{\text {ads }} \cdot \mathrm{dSi}_{\text {free }}
$$

The total concentration of the $\mathrm{dSi}$ in aggregate $\left(\overline{\mathrm{dSi} i_{\text {agg }}}\right)$ is calculated by the adsorption version of the model at the end of the dissolution. $\overline{\mathrm{dSi}}$ agg is the sum of the $\mathrm{dSi}_{\text {free }}$ and $\mathrm{dSi}_{\text {ads }}$ in each slice of the aggregate, integrated over the whole aggregate. $\overline{\mathrm{dSi}} \mathrm{agg}_{\text {ag }}$ is compared to the internal dSi concentrations measured in laboratory experiments. In the latter, the internal dSi is obtained by resuspending aggregates in artificial seawater containing no dSi. The fact that the medium is dSi-free causes adsorbed dSi to desorb. The dSi analysed in the filtrate after resuspension and breakage of the sampled aggregate is the total internal dSi concentration of the aggregate $\overline{\mathrm{dSi}}$ agg .

In the adsorption version of the model, both the diffusion rate of $\mathrm{dSi}_{\text {free }}$ (Eq. 8), and the dissolution rate (Eq. 9) are affected by adsorption (Berner 1980):

$$
D_{\text {eff }}=D_{\mathrm{dSi}} /\left(1+k_{\text {ads }}\right)
$$




$$
\begin{aligned}
R_{\mathrm{dSi}}= & \frac{1}{\phi} \cdot k_{\mathrm{dis}} \cdot \mathrm{bSiO}_{2} \cdot\left(\mathrm{MW}_{\mathrm{bSiO} 2} \cdot 10^{-6}\right) . \\
& \left(1-f_{\text {viab }}\right) \cdot\left(\frac{1}{1+k_{\mathrm{ads}}}\right) \cdot\left(1-\frac{\overline{\mathrm{dSi}_{\text {free }}}}{\mathrm{dSi}_{\mathrm{eq}}}\right)
\end{aligned}
$$

In contrast, in the retention version, the dissolution rate depends only on the $\overline{\mathrm{dSi}}$ agg (compare Eqs. 5 \& 9).

In both versions, the model-predicted $\mathrm{dSi}_{\text {ext }}$ is obtained by computing the diffusion flux from the aggregate into the surrounding seawater, using an average volume of seawater per aggregate consistent with the experimental conditions (total volume of the tank divided by the number of aggregates; Table 1). The surrounding seawater is assumed to be perfectly mixed, and the boundary condition $\mathrm{dSi}_{\text {ext }}=$ $\mathrm{dSi}_{\text {agg }}$ is imposed at the aggregate-medium interface (i.e. at $r=r_{\text {agg, }}$ Table 1). After each time step, the value of $\mathrm{dSi}_{\text {ext }}$ is updated, taking into account the mass of dSi that has diffused out of the aggregate during the time step. The computed temporal evolution of $\mathrm{dSi}_{\text {ext }}$ is then compared to the experimental $\mathrm{dSi}_{\text {ext }}$ concentrations versus time measured in the seawater medium surrounding the aggregates.

Additionally, the $\mathrm{dSi}$ porewater concentration measured at the end of the experiments is compared to the integrated concentration of $\mathrm{dSi}$ within the aggregate $\left(\overline{\mathrm{dSi}} i_{\text {agg }}\right)$, computed at the end of the model run using Eq. (10):

$$
\overline{\mathrm{dSi}_{\text {agg }}}=\frac{\sum_{r=0}^{r_{\text {agg }}} \mathrm{dSi}_{\text {agg }}\left(r_{\text {agg }}\right) \cdot \frac{4 \pi}{3} \cdot\left[\left(r_{\text {agg }}+\delta r_{\text {agg }}\right)^{3}-r_{\text {agg }}^{3}\right]}{\frac{4 \pi}{3} \cdot r_{\text {agg }}^{3} \cdot \phi}
$$

where $r_{\text {agg }}$ is the aggregate radius, $\operatorname{dSi}_{\text {agg }}\left(r_{\text {agg }}\right)$ is the dSi concentration of the layer between $r_{\text {agg }}+\delta r_{\text {agg }}$ and $r_{\text {agg }}$ at $t$ final, and $\phi$ is the porosity of the aggregate.

The numerical solution of the model equations uses spatial steps of $\delta r=r_{\text {agg }} / 50$ for the retention scenario. The number of aggregate layers is decreased to 3 in the adsorption scenario, without affecting the results. In all model runs, the time steps are $10 \mathrm{~h}$. Parameter values and initial conditions for the simulations are summarized in Table 1.

\section{Input data and model parameterization}

Synopsis of the experimental data

The model output was statistically compared to an experimental set of data obtained during 4 dissolu- tion experiments, 2 with Skeletonema marinoi and 2 with Chaetoceros decipiens aggregates. The reaction-diffusion model developed here is parameterized using both experimental measurements done during these dissolution experiments and data from the literature (Table 1). Experimental conditions are described in detail in the study by Moriceau et al. (2007b), and a brief summary is given here. During the dissolution experiments, aggregated and nonaggregated diatoms were kept in the dark at $13^{\circ} \mathrm{C}$. Continuous sinking was mimicked by using roller tables for diatom aggregates and shaker tables for free diatoms. Aggregate concentrations were 100 aggregates $\mathrm{l}^{-1}$ for $S$. marinoi and 80 aggregates $\mathrm{l}^{-1}$ for C. decipiens. Aggregate characteristics needed to parameterize the model (Table 1) were measured at the end of the dissolution experiments. Note that these aggregate characteristics were similar to those reported for natural aggregates.

Diatom viability was determined by counting the ratio of diatoms stained with fluorescein diacetate over the total number of diatoms at the beginning of the experiment on C. decipiens $(50 \%$ of the cells metabolically active in aggregates; unpubl. data). At least $30 \%$ of the aggregated S. marinoi were metabolically active, but the results of Garvey et al. (2007) suggest that the rapid fading of the fluorescence of the assay used may invalidate this method for $S$. marinoi, our second model species.

Concentrations of $\mathrm{dSi}$ in the porewater of 20 aggregates were determined by isolating each aggregate in artificial seawater containing no nutrients. dSi concentration inside the aggregate was calculated using the visible volume $\left(V_{\text {agg }}\right)$ of each individual aggregate determined from its width $\left(W_{\text {agg }}\right)$ and length $\left(L_{\text {agg }}\right)$ as the volume of an equivalent ellipsoid $\left(V_{\text {agg }}=\pi / 6 \times W^{2}\right.$ agg $\times$ $L_{\text {agg }}$ ). Because the artificial seawater used to isolate each aggregate contained no $\mathrm{dSi}$, the $\mathrm{dSi}$ concentration measured in the aggregate porewater is the total $\mathrm{dSi}_{\text {agg }}$ concentration. Under such conditions, the potentially adsorbed dSi would desorb. Internal dSi concentration $\left(\mathrm{dSi}_{\text {agg }}\right)$ measured on 20 different aggregates for each of the 2 diatom species was $80 \mu \mathrm{M}$.

During these 2 experiments, we measured apparent dissolution rates by following the temporal evolution of $\mathrm{dSi}$ concentrations in the surrounding seawater of aggregates. Apparent dissolution rates were calculated as the slope of the temporal evolution of dSi concentrations normalized to the initial $\mathrm{bSiO}_{2}$ concentrations. For $S$. marinoi aggregates, the apparent $\mathrm{bSiO}_{2}$ dissolution rate constant $\left(k_{\mathrm{dis}}\right)$ was $4.8 \mathrm{nmol}$ $\mathrm{g}^{-1} \mathrm{bSiO}_{2} \mathrm{~s}^{-1}$ compared to an effective dissolution rate constant of $10.5 \mathrm{nmol} \mathrm{g}^{-1} \mathrm{bSiO}_{2} \mathrm{~s}^{-1}$ for freely suspended 
S. marinoi. For $C$. decipiens, an apparent $k_{\text {dis }}$ of $4.5 \mathrm{nmol} \mathrm{g}^{-1}{ }_{\mathrm{bSiO} 2} \mathrm{~s}^{-1}$ was obtained for aggregated cells and an average effective $k_{\text {dis }}$ of $11.4 \mathrm{nmol}$ $\mathrm{g}^{-1} \mathrm{bSiO} 2 \mathrm{~s}^{-1}$ for freely suspended cells.

Using the likelihood method described below, the best model fit to the experimental data was selected using (1) a large range of $k_{\text {dis }}$ determined from the dissolution rates measured in the experimental study $\left(k_{\mathrm{dis}}=1\right.$ to $\left.15 \mathrm{nmol} \mathrm{g}^{-1} \mathrm{bSiO} 2^{-1}\right)$, and (2) a large range of retention factors ( 1 to 300 ), in order to bracket the estimation of 200 calculated by Brzezinski et al. (1997), or a range of adsorption constants (0 to 10) framing the estimated values of Aller (1983) and Aller \& Aller (1998).

\section{Statistics}

The $\overline{\mathrm{dSi}} \mathrm{igg}_{\text {agg }}$ and $\mathrm{dSi} \mathrm{i}_{\text {ext }}$ estimated by each model version for each species were compared to the respective experimental data. The goodness of fit was estimated using the log likelihood $(\log (L))$ method with Eq. (11) (Armstrong et al. 2002). This approach depends on the amount of data points fitted, and allows a direct comparison of the fit obtained by the 2 model versions using the deviation at each data point between model and data:

$$
\log (L)=-\frac{N}{2} \cdot \log \left(\frac{\sum\left(\log \left(\hat{C}_{j}\right)-\log \left(C_{j}\right)\right)^{2}}{N}\right)
$$

where $N$ is the number of data points, $C_{j}$ is the measured concentration $\left(\mathrm{dSi}_{\text {ext }}\right.$ or $\left.\overline{\mathrm{dSi}} \mathrm{igg}_{\text {agg }}\right)$ for the data point number $j$, and the $\hat{C}_{j}$ is the corresponding model prediction. As a matter of comparison, note that a 2-point difference in the log likelihood is considered to be a sufficient improvement of the fit to justify adding a supplementary parameter to the model. Here our 2 model versions have the same number of parameters; thus, we fixed the threshold at 1 point of log likelihood to decide whether one version gives a better fit than the other.

\section{Model experiments}

The 2 model experiments compared reconstructed dSi concentrations to an experimental set of data, built from 2 dissolution experiments on each species. The benefit is to increase the amount of data while taking into account the large heterogeneity of the aggregates. With the first modelling experiment, we assessed which scenario, viz. adsorption or retention, yields the best fit to our experimental external and internal dSi concentrations and most probably repre- sents the dSi transport in aggregates. The second modelling experiment evaluated the relative contribution of viability vs. elevated $\mathrm{dSi}_{\mathrm{agg}}$ to explain the observed decrease in the effective $\mathrm{bSiO}_{2}$ dissolution rates of aggregated diatoms compared to freely suspended diatoms. A sensitivity analysis run on the best version of the model investigated its sensitivity to specific input parameters, namely viability, porosity and $\mathrm{dSi}_{\mathrm{agg}}$.

\section{Expt 1}

Retention assumes that diffusion of dSi within an aggregate is slower than in seawater. Consequently, retention processes reduce the net flux of dSi out of aggregates but have no direct impact on $\mathrm{bSiO}_{2}$ dissolution (Eqs. 4 \& 5). In contrast, adsorption of $\mathrm{dSi}$ within the aggregate matrix directly impacts the transport of dSi out of the aggregate and the $\mathrm{bSiO}_{2}$ dissolution rate (Eq. 9). If adsorption processes take place in the aggregate, the silicic acid in the aggregate porewater is divided into 2 pools: the free dSi $\left(\mathrm{dSi}_{\text {free }}\right)$, which can diffuse, and the adsorbed $\mathrm{dSi}$ $\left(\mathrm{dSi}_{\mathrm{ads}}\right)$, which is immobile. The ratio of free $\mathrm{dSi}$ and adsorbed $\mathrm{dSi}$ is constant and equal to the linear adsorption constant $k_{\text {ads }}$. The calculation of the log likelihood (Eq. 11) allows us to compare the goodness of fit to the experimental data of each model version. Both versions of the model give an effective $\mathrm{bSiO}_{2}$ dissolution rate constant that can be directly compared to the dissolution rate constant measured for freely suspended diatoms. In this first experiment where only dSi transport was investigated, the viability was set to 0 while the model was otherwise parameterized using the values given in Table 1.

\section{Expt 2}

We assessed the relative contribution of the high dSi concentrations and the high diatom viability measured in the experimental study to the difference between the effective $\mathrm{bSiO}_{2}$ dissolution rate constant calculated for aggregated and measured for freely suspended diatoms. Two extreme scenarios are considered: (1) $\hat{k}_{\text {dis_agg }}\left(\mathrm{dSi}_{\text {agg }}\right)$ is estimated from a model run with dSi porewater concentrations set to the experimental average of $80 \mu \mathrm{M}$ and diatom viability set to 0 , implying that no metabolically active diatoms are aggregated and that all frustules undergo dissolution; (2) $\hat{k}_{\text {dis_agg }}\left(f_{\text {viab }}\right)$ is calculated from the model run with $\mathrm{dSi}_{\text {free }}$ set to a constant minimal value 
corresponding to the initial $\mathrm{dSi}_{\text {ext }}\left(6 \mu \mathrm{M}_{i}\right.$ see Table 1$)$, while experimental viability $(40 \%)$ is used to parameterize the model. For each model setting, the model calculates the best effective dissolution rate constant $\hat{k}_{\text {dis_agg }}(P)$ needed to reconstruct the observed temporal evolution of dSi concentrations outside the aggregates with these settings. The relative contribution of elevated dSi concentrations (Step 1) and diatom viability (Step 2) in explaining the reduced effective dissolution rates of aggregated diatoms compared to freely suspended diatoms is then evaluated using the ratio $\alpha$ :

$$
\alpha(P)=\frac{\hat{\boldsymbol{k}}_{\text {dis_agg }}(P)-\hat{\boldsymbol{k}}_{\text {dis_agg }}}{k_{\text {dis_FC }}-\hat{\boldsymbol{k}}_{\text {dis_agg }}}
$$

where $\hat{k}_{\text {dis_agg }}$ is the modelled effective dissolution rate constant obtained in the first experiment with settings from Table 1 , while $\hat{k}_{\text {dis_agg }}(P)$ is the effective dissolution rate calculated by the model when only the parameter $P$ (i.e. successively $\mathrm{dSi}_{\text {agg }}$ and $f_{\text {viab }}$ ) impacts dissolution. $k_{\text {dis_FC }}$ is the experimental $\mathrm{bSiO}_{2}$ dissolution rate coefficient of the freely suspended cells.

\section{Sensitivity tests}

By running the best model using a range of fixed values of $f_{\text {viab }}$ from 0 to 1 , a porosity ranging from 0.75 to 0.99 and a range of fixed values of $\mathrm{dSi}_{\text {agg }}$ from 20 to $140 \mu \mathrm{M}$, we assessed the sensitivity of our model to parameterization when deriving values of $k_{\text {ads }}$ and $k_{\text {dis }}$.

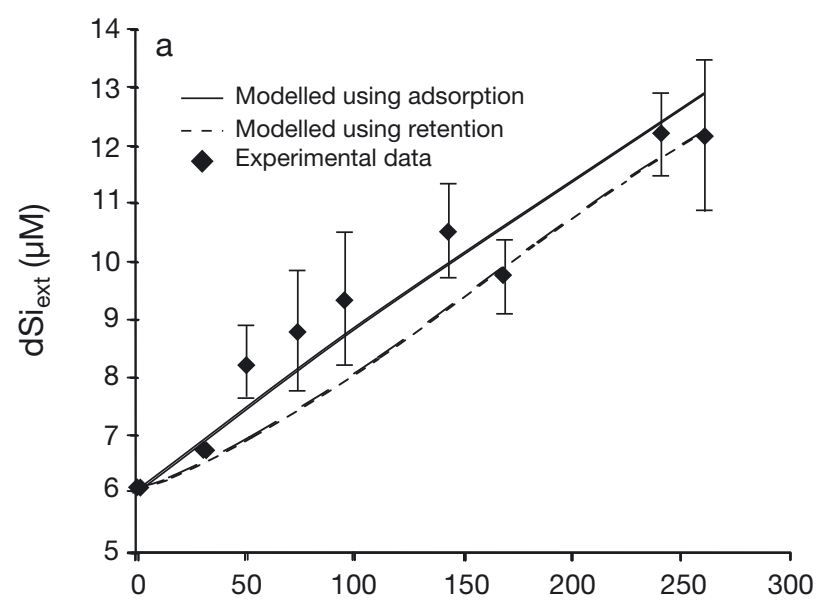

\section{RESULTS AND DISCUSSION}

\section{Model Expt 1: Which process best explains dSi accumulation in aggregates: retention or adsorbtion?}

The large heterogeneity of the aggregates is illustrated by a strong variability of the external dSi measurements as shown in Fig. 1a for Skeletonema marinoi. Despite the variability of the experimental data set, both the retention and the adsorption versions of the model reproduce reasonably well the measured temporal variation in the dSi concentration in the seawater surrounding aggregates ( $\mathrm{dSi}_{\text {exti }}$ Fig. $1 \mathrm{a}, \mathrm{b})$ and the final average dSi concentration inside aggregates $\left(\overline{\mathrm{dSi}_{\text {agg }}} ;\right.$ Fig. 2$)$ for the 2 species. In the adsorption model, the increase in $\overline{\mathrm{dSi}_{\text {agg }}}$ is continuous over time (Fig. 2a). When the model reconstructs the high $\overline{\mathrm{dSi}_{\text {agg }}}$ measured inside aggregates by decreasing the transport of dSi through the matrix (retention processes), dSi $\mathrm{agg}_{\text {arst }}$ increases rapidly over time to $\sim 90 \mu \mathrm{M}$ (at the centre of the aggregate) and then more slowly to almost $150 \mu \mathrm{M}$ (at the centre of the aggregate) with a final average of $80 \mu \mathrm{M}$ (Fig. 2b). By contrast, the dSi concentrations are homogeneous in the aggregate in the adsorption scenario (Fig. 2a). Despite a good reconstruction of the internal average and external dSi concentrations, the 2 different processes give a very different description of the physico-chemical conditions possibly existing inside aggregates. Unfortunately, neither the gradient of dSi inside an aggregate nor the evolution of dSi over time in an aggregate can be measured to help identify the better of the 2 processes.

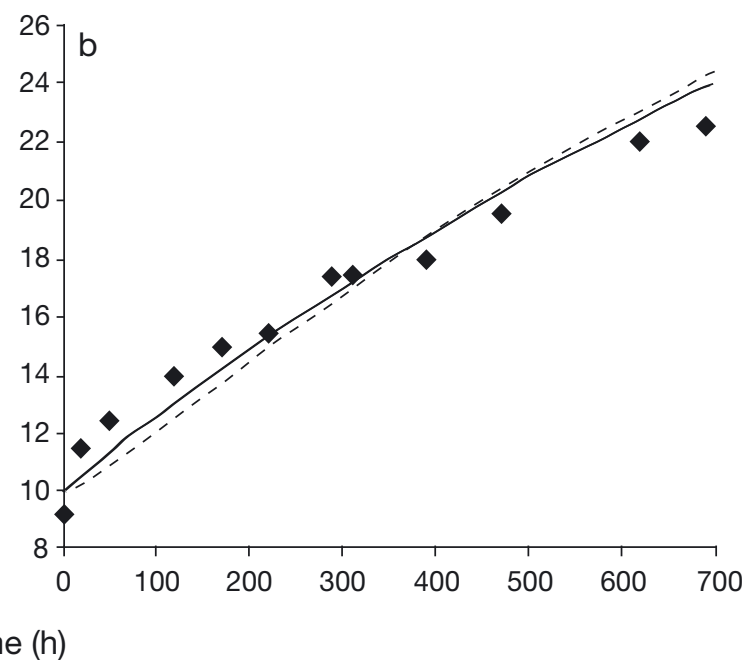

Fig. 1. Temporal evolution of the external silicic acid (dSi) concentrations ( $\mathrm{dSi}_{\mathrm{ext}}$ ) for (a) Skeletonema marinoi and (b) Chaetoceros decipiens from the adsorption (solid line) or the retention (dashed line) model version and experimental data (diamonds). 

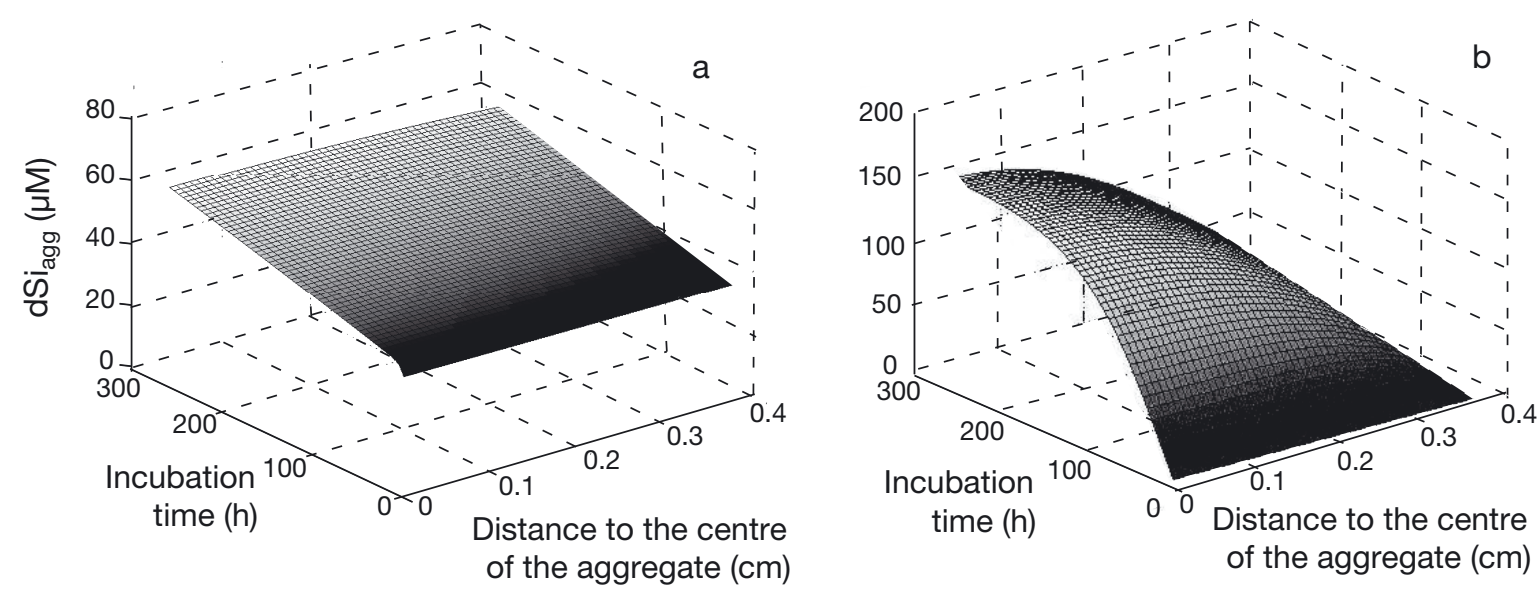

Fig. 2. Temporal and spatial evolution of the internal silicic acid (dSi) concentration of an aggregate (dSi $\left.i_{a g g}\right)$ calculated for Skeletonema marinoi using (a) the adsorption and (b) the retention version of the model

The model calculates retention factors of 138 for S. marinoi aggregates and 128 for Chaetoceros decipiens aggregates. As shown by Eq. (4), such retention factors imply a decrease in the effective dSi diffusion constant by 2 orders of magnitude compared to the value of $0.80 \times 10^{-5} \mathrm{~cm}^{2} \mathrm{~s}^{-1}$ measured in seawater at $15^{\circ} \mathrm{C}$ (Rebreanu et al. 2008) and corrected for tortuosity (Boudreau 1997). Although the modelderived retention factors are in the range of values (20-200) postulated from measurements of dSi within porewater aggregates (Brzezinski et al. 1997), they are high compared to the value of 1.1 extrapolated from direct measurement of gas diffusion in aggregates (Ploug \& Passow 2007). The adsorption version of the model calculates adsorption coefficients of 2.3 and 5.3. Such adsorption coefficients lead to a decrease in diffusion by a factor of 3.3 and 6.3 (see Eq. 8). To our knowledge, the study of Aller (1983) is the only study that directly measured the dSi diffusion constant through organic mucus. Despite probable differences in the chemical composition of the aggregate matrix and the mucus-rich micro-environment of polychaete and crustacean burrows, the author measured a similar decrease in the dSi diffusion constant (factor of 4.3). By contrast, the retention model requires retention factors that are unrealistically high.

This assessment is consistent with the log likelihood calculated for each model run (Table 2). The fit obtained with the adsorption model is appreciably better than with the retention version for both $S$. marinoi and $C$. decipiens (Table 2). For the temporal reconstruction of the external $\mathrm{dSi}$ and the internal $\mathrm{dSi}$ for $S$. marinoi aggregates, the best fit gives a log likelihood of 29.8 with an adsorption coefficient $\left(k_{\text {ads }}\right)$ of 5.3 and $\mathrm{a} \mathrm{bSiO}_{2}$ dissolution rate constant $\left(k_{\text {dis }}\right)$ of $4.7 \mathrm{nmol} \mathrm{gbSiO}^{-1} \mathrm{~s}^{-1}$. Best fits of external and internal concentrations of $\mathrm{dSi}$ of $C$. decipiens aggregates yield a log likelihood of 27.6 using a $k_{\text {ads }}$ of 2.3 and $k_{\text {dis }}$ of $4.6 \mathrm{nmol} \mathrm{gbSiO}^{-1} \mathrm{~s}^{-1}$. These log likelihood values are 2 points above those of the fits obtained with the retention model version (Table 2). A 2-point increase in log likelihood has been considered in other studies (Armstrong et al. 2002, Moriceau et al. 2009) to be good enough to justify an increase in model complexity. In our study, the model versions had the same number of parameters. The log likelihood increase establishes the superiority of the adsorption version of the model over the retention model. dSi accumulation within aggregates may best be explained by processes approaching a dSi 'adsorption' rather than a 'retention' scenario.

Adsorption processes in aggregates induce an accumulation of dSi inside the aggregates. The silicic acid is mainly adsorbed, and only $20 \%$ is 'free'. Free

Table 2. Model results for the first modelling experiment. $\hat{k}_{\text {dis_agg }}$ : modelled effective dissolution rate constant; $f_{\text {ret }}$ : retention factor; $k_{\text {ads }}$ : linear adsorption constant; $\mathrm{bSiO}_{2}$ : biogenic silica

\begin{tabular}{|c|c|c|c|c|c|}
\hline Species & $\begin{array}{c}\text { Model } \\
\text { version }\end{array}$ & $\begin{array}{c}\hat{k}_{\text {dis_agg }}(\mathrm{nmol} \\
\left.\mathrm{g}_{\mathrm{bSiO} 2}^{-1} \mathrm{~s}^{-1}\right)\end{array}$ & $f_{\text {ret }}$ & $k_{\text {ads }}$ & $\begin{array}{c}\text { Log } \\
\text { likelihood }\end{array}$ \\
\hline \multirow{2}{*}{$\begin{array}{c}\text { Skeletonema } \\
\text { marinoi }\end{array}$} & Retention & 5.8 & 138 & - & 26.6 \\
\hline & Adsorption & 4.7 & - & 5.3 & 29.8 \\
\hline \multirow{2}{*}{$\begin{array}{c}\text { Chaetoceros } \\
\text { decipiens }\end{array}$} & Retention & 4 & 128 & - & 24.4 \\
\hline & Adsorption & 4.6 & - & 2.3 & 27.6 \\
\hline
\end{tabular}


$\mathrm{dSi}$ is exchanged with the external environment through the diffusion process. Consequently, the concentration of free dSi is similar to the external concentration as shown by comparison between Fig. 3 and Fig. 1b, which concurs with the estimations of Ploug \& Passow (2007) of dSi diffusion in aggregates. The first candidates to explain dSi adsorption are TEP, as they consist of very surface-active substances and contribute considerably to the aggregate matrix (Passow 2002). The initial volume fraction of TEP (amount of TEP per volume of aggregate) in C. decipiens aggregates (879 $\mu \mathrm{g}$ of xanthan equivalent $\mathrm{cm}^{-3}$ ) is more than 3 times that of $S$. marinoi aggregates $\left(258 \mathrm{\mu g}\right.$ of xanthan equivalent $\left.\mathrm{cm}^{-3}\right)$, whereas the $k_{\text {ads }}$ value is lower for $C$. decipiens. The fact that dSi adsorption is not directly related to the total TEP concentration could invalidate our guess or may also suggest that only some constituents of TEP are involved in the dSi adsorption. Chemical composition of TEP is complex and varies depending on the organisms involved during their formation and modification (Passow 2002, Verdugo et al. 2004, Bhaskar et al. 2005, Gogou \& Repeta 2010). Adsorption of silver ions on exopolysaccharides (EPS), known to be precursors and constituents of the TEP, varies with the chemical composition of the EPS (Deschatre et al. 2014). Other substance classes may also play the role of $\mathrm{dSi}$ sorbent. Chemical adsorption may include the formation of organo-silicon complexes as observed

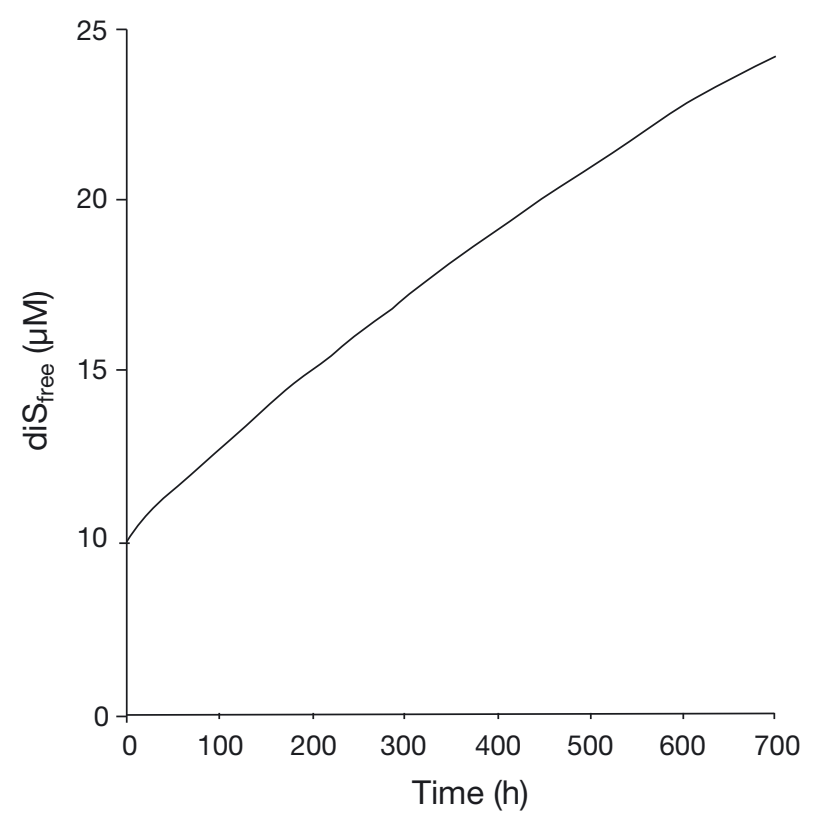

Fig. 3. Temporal evolution of the free silicic acid (dSi) concentrations $\left(\mathrm{dSi}_{\text {freee }}\right)$ inside a Chaetoceros decipiens aggregate predicted by the adsorption model version using parameters detailed in Table 2 by Bennett (1991) or the formation of Si-O-C esterbonded complexes or hydrogen-bonded complexes (Iler 1977, Bennett 1991, Frampton \& Zelisko 2009). Such complexes could form in the aggregate matrix, but also on the diatom cell surfaces, or they could be precursors for the silica deposition observed in specific conditions on the bacteria cell surface (Benning et al. 2004).

\section{Model Expt 2}

Model Expt 1 establishes that the adsorption version of the model best represents $\mathrm{bSiO}_{2}$ dissolution in aggregates. Another important result from this modelling experiment is that $\mathrm{bSiO}_{2}$ dissolution is not only apparently but effectively lower in aggregates than in freely suspended diatoms. With this second modelling experiment, we aimed to evaluate the contribution of elevated dSi concentrations and longer diatom viability to this effective decrease. $\mathrm{bSiO}_{2}$ of aggregated and freely suspended frustules is chemically and structurally identical, as diatoms were grown in the exact same conditions. As a consequence, differences in the effective dissolution rate between aggregated and freely suspended cells result from differences in the biological state or in the local environment surrounding aggregated and freely suspended frustules. Mathematically, for each parameter added to Eq. (9) that effectively impacts the $\mathrm{bSiO}_{2}$ dissolution in aggregates, the effective dissolution rate constant $\hat{k}_{\text {dis_agg }}$ estimated by the model should get closer to the effective dissolution rate constant measured for freely suspended cells. With Eq. (9), the model considers the contribution of 2 parameters: the internal dSi concentration and the percentage of metabolically active diatoms $\left(f_{\text {viab }}\right)$. The relative contribution of each parameter is estimated using the $\alpha$ ratio (Eq. 12). When $\alpha=0$, the parameter has no effect on $\mathrm{bSiO}_{2}$ dissolution, whereas when $\alpha=1$, the parameter fully explains the decrease in the $\mathrm{bSiO}_{2}$ dissolution rate measured when diatoms are in aggregates compared to when they are freely suspended.

To assess the relative contribution of the $\mathrm{dSi}_{\mathrm{agg}}$, the model first calculates the dissolution rate constant by setting $d \mathrm{Si}_{\text {free }}$ equal to the experimental final average value of $80 \mu \mathrm{M}$ (see Eq. 9 and Table 1) and by setting the viability $\left(f_{\text {viab }}\right)$ to 0 . In this scenario, only $d \mathrm{Si}_{\text {agg }}$ concentrations in aggregates and $k_{\text {ads }}$ affect the frustule dissolution. The model fits yield $\hat{k}_{\text {dis_agg }}\left(\mathrm{dSi}_{\text {agg }}\right)$ equal to the effective dissolution rate constants $\hat{k}_{\text {dis_agg }}$ calculated in Expt $1\left(4.6 \mathrm{nmol} \mathrm{g}_{\mathrm{bSiO} 2}{ }^{-1} \mathrm{~s}^{-1}\right.$ for C. decipiens, respectively; Table 3 ). This dissolution 
rate deviates significantly from the dissolution rate constant of freely suspended diatom cells, $k_{\text {dis_FC }}$ (Table 3), that the model was supposed to calculate if $\mathrm{dSi}_{\text {agg }}$ were responsible for the total decrease in the apparent $\mathrm{bSiO}_{2}$ dissolution rates measured in aggregates. The relative contribution given by $\alpha$ is 0 . The decrease in the $\mathrm{bSiO}_{2}$ dissolution rates measured for aggregated diatoms compared to freely suspended diatoms is not due to dSi accumulation inside the aggregates.

The relative contribution of diatom viability is estimated by calculating $\hat{k}_{\text {dis_agg }}\left(f_{\text {viab }}\right)$ using the following setting: $d \mathrm{Si}_{\text {free }}$ equals $d \mathrm{Si}_{\text {ext, }}$ and $f_{\text {viab }}$ equals the experimental value of 0.5 . In this scenario, $\hat{k}_{\text {dis_agg }}$ $\left(f_{\text {viab }}\right)$ is $7.2 \mathrm{nmol} \mathrm{g} \mathrm{bSiO2}^{-1} \mathrm{~s}^{-1}$ for $C$. decipiens. This modelled dissolution rate constant is bracketed by the effective dissolution rate constant of aggregated cells $\left(\hat{k}_{\text {dis_agg }}=4.5 \mathrm{nmol} \mathrm{g} \mathrm{bSSiO}^{-1} \mathrm{~s}^{-1}\right)$ and the experimental dissolution rate constant of free cells $\left(k_{\text {dis_FC }}=\right.$ $11.5 \mathrm{nmol} \mathrm{g}_{\mathrm{bSiO} 2}{ }^{-1} \mathrm{~s}^{-1}$ ). The relative contribution estimated with $\alpha$ suggests that viability explains $39 \%$ of the reduction of the $\mathrm{bSiO}_{2}$ dissolution rate constant when diatom frustules are in aggregates.

\section{Sensitivity analysis of the adsorption model}

The modelling dissolution can be very much dependent on the parameterization used. Parameterization described Table 1 has been fixed using experimental measurements. While laboratory-made aggregates are less variable than in situ aggregates, results described by Moriceau et al. (2007b) showed

Table 3. Summary of the $\mathrm{bSiO}_{2}$ dissolution rate constants used in the second modelling experiment to evaluate the relative contributions, $\alpha\left(\mathrm{dSi}_{\mathrm{agg}}\right)$ and $\alpha\left(f_{\text {viab }}\right)$, of the internal $\mathrm{dSi}$ concentration $\left(\mathrm{dSi}_{\mathrm{agg}}\right)$ and of the fraction of metabolically active diatoms $\left(f_{\text {viab }}\right)$, respectively, to slow down the $\mathrm{bSiO}_{2}$ dissolution in Chaetoceros decipiens aggregates. All $k_{\text {dis }}$ values are in $\mathrm{nmol} \mathrm{g}_{\mathrm{bSiO} 2}{ }^{-1} \mathrm{~s}^{-1}$

\begin{tabular}{|lcr|}
\hline & Abbrev. & Value \\
\hline Experimental constants for: & & \\
free diatoms & $k_{\text {dis_FC }}$ & 11.5 \\
aggregates & $k_{\text {dis_agg }}$ & 4.5 \\
Modelled effective & $\hat{k}_{\text {dis_agg }}$ & 4.6 \\
constant for aggregate & & \\
Modelled constant considering only the impact of: & \\
dSi $i_{\text {agg }}$ & $\hat{k}_{\text {dis_agg }}\left(\mathrm{dSi}_{\text {agg }}\right)$ & 4.6 \\
$f_{\text {viab }}$ & $\hat{k}_{\text {dis_agg }}\left(f_{\text {viab }}\right)$ & 7.2 \\
Relative contribution of: & $\alpha\left(\mathrm{dSi} i_{\text {agg }}\right)$ & 0 \\
dSi $i_{\text {agg }}$ & $\alpha\left(f_{\text {viab }}\right)$ & 0.39 \\
$f_{\text {viab }}$ &
\end{tabular}

that measurements of $\overline{\mathrm{dSi}}$ agg can be highly variable. Viability was not very variable between aggregates but may be very different from in situ viability, as marine aggregates are often made up of detritus. The other tested parameter was porosity, as this parameter was determined using TEP contribution to the aggregate volume measured in another study on different aggregates. We ran the model many times with different settings of $f_{\text {viab }} \phi$ and $\overline{\mathrm{dSi}}$ agg to evaluate the impact of these parameters on the modelled adsorption and dissolution constants. In the range of porosities tested, dissolution rate constants estimated by the model varied by a maximum of $0.3 \mathrm{nmol}$ $\mathrm{g}_{\mathrm{bSiO} 2}{ }^{-1} \mathrm{~s}^{-1}$, while the modelled adsorption constants varied by a maximum of 0.2 . Thus the model is not sensitive to the porosity parameterization in the range tested. The results for the 2 other parameters are summarized in Fig. 4.

Model-derived values of $k_{\text {ads }}$ are not sensitive to viability (Fig. 4a), in contrast to dissolution rate constants $\left(\hat{k}_{\text {dis_agg }}\right)$. When less than $50 \%$ of the diatoms show respiratory activity $\left(f_{\text {viab }}<0.5\right)$, the dissolution constant is less variable, but for higher values, model-derived $\hat{k}_{\text {dis_agg }}$ increases exponentially (Fig. $4 \mathrm{~b}$ ). The degree of uncertainty in the experimental determinations of the viability of aggregated cells was around $10 \%$ for the same species. The sensitivity of $\hat{k}_{\text {dis_agg }}$ to viability could explain the small decoupling between modelled and experimental $\mathrm{dSi}_{\text {ext }}$ after $480 \mathrm{~h}$ (Fig. 1b). While experimental tests on the impact of aggregation on cell viability show that viability can be maintained in aggregates for up to $480 \mathrm{~h}$, there are indications that cell viability drops off at longer time scales (Garvey et al. 2007). Thus, with the proper experimental data, the model could be improved by including a time-dependent viability fraction, but such parameters would be difficult to constrain for a general model and at in situ viabilities, the model is not so sensitive that the accuracy of the $k_{\text {dis }}$ calculation would warrant an increase in the model's complexity.

Experimental measurements of the averaged internal dSi concentrations $\left(\overline{\mathrm{dSi}_{\text {agg }}}\right)$ in aggregates varied between 20 and $100 \mu \mathrm{M}$. For this range of $\overline{\mathrm{dSi}_{\mathrm{agg}}}$, the sensitivity analysis revealed that $k_{\text {dis }}$ is only slightly affected (Fig. 4d). To a large degree this is because over the range of $\overline{\mathrm{dSi}}$ agg considered $(20-100 \mu \mathrm{M})$, the aggregate pore solution remains highly undersaturated with respect to $\mathrm{bSiO}_{2}$ and, therefore, the $R_{\text {dis }}$ is insensitive to dSi concentrations. In contrast, the linear dependence between model-derived $k_{\text {ads }}$ values and $\overline{\mathrm{dSi}} \mathrm{igg}_{\text {agg }}$ (Fig. 4c) implies an uncertainty of up to $50 \%$ for the $k_{\text {ads }}$ values reported here. 

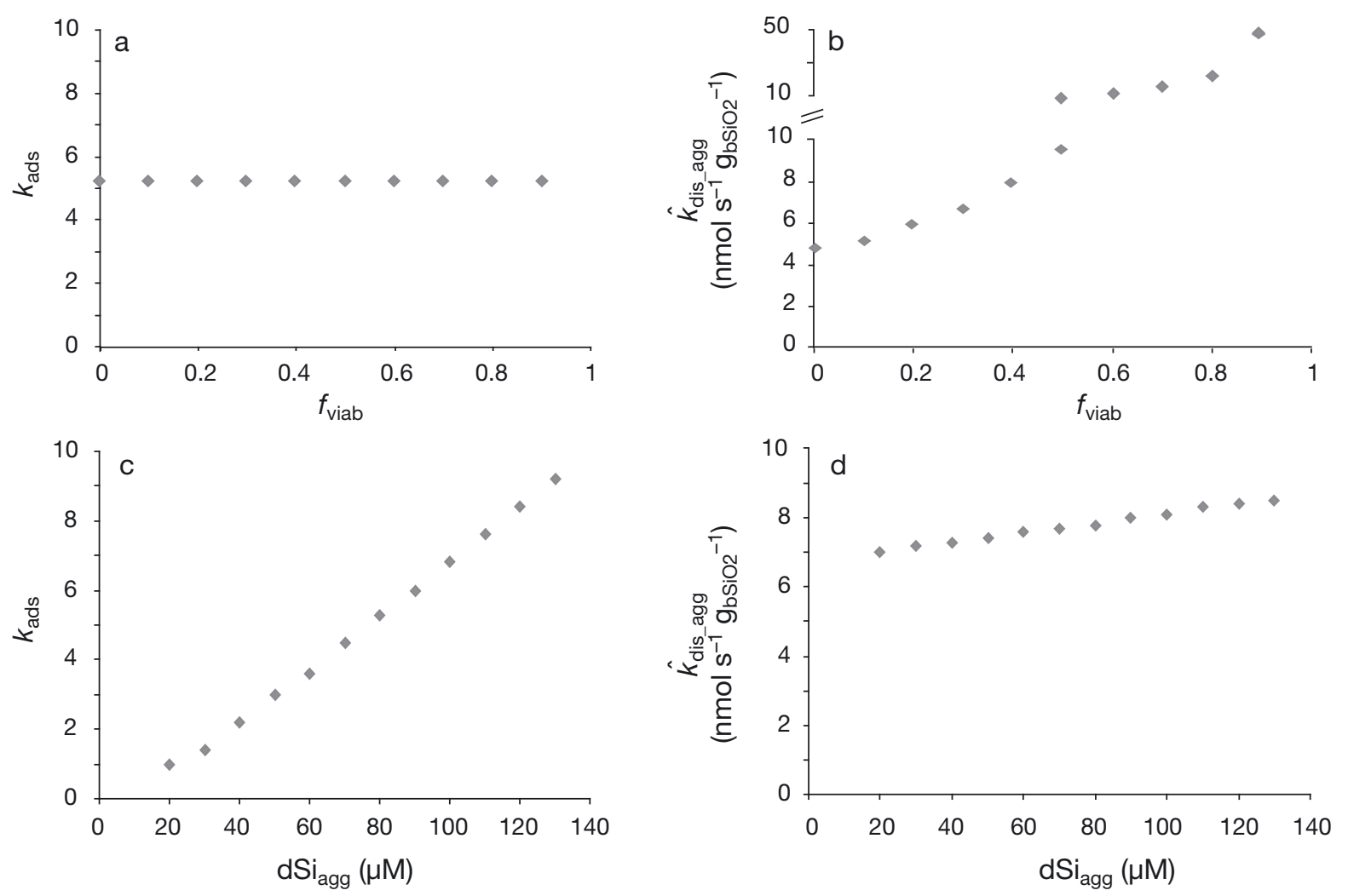

Fig. 4. Sensitivity analysis on the adsorption version of the model to reconstruct the dissolution. (a) Sensitivity of the linear adsorption constant $k_{\text {ads }}$ estimation to diatom viability, $f_{\text {viab. }}$ (b) Sensitivity of the modelled effective dissolution rate constant $\hat{k}_{\text {dis_agg }}$ to $f_{\text {viab. }}$ (c) Sensitivity of the $k_{\text {ads }}$ estimation to internal silicic acid (dSi) concentration, dSi $i_{\text {agg }}$. (d) Sensitivity of the $\hat{k}_{\text {dis_agg }}$ to $\mathrm{dSi}_{\text {agg }}$

In summary, viability parameterization for C. decipiens was reliable enough to suggest that diatom viability explains $39 \%$ of the decrease in apparent $\mathrm{bSiO}_{2}$ dissolution rates observed in aggregates compared to freely suspended cells. Regarding the adsorption process, the $k_{\text {ads }}$ parameter is dependent on the parameterization of the internal $\mathrm{dSi}$, which is technically difficult to measure. $k_{\text {ads }}$ evolved from 1 to 10 when $\mathrm{dSi}_{\text {agg }}$ varied from 20 to $100 \mu \mathrm{M}$.

In the 2 experiments, the dissolution rate constants calculated by the model to reproduce the dSi dynamic in and out of an aggregate were systematically lower than the $\mathrm{bSiO}_{2}$ dissolution rate constants experimentally measured for free suspended cells. With a perfect representation of the Si cycling in an aggregate and a perfect parameterization of all parameters influencing the $\mathrm{bSiO}_{2}$ dissolution and the $\mathrm{dSi}$ transport, the effective $\mathrm{bSiO}_{2}$ dissolution rate calculated by the model should be exactly the experimental measurement of the $\mathrm{bSiO}_{2}$ dissolution rate in freely suspended diatoms. However, while realistic, the model is a simplification of an aggregate leading to partial representation of the $\mathrm{Si}$ cycle in an aggre- gate. All parameters possibly changing $\mathrm{bSiO}_{2}$ dissolution in an aggregate were not represented in the model built for this study. Moreover, the parameterization sometimes had to be approximated due to measurement uncertainty or even to the impossibility to directly measure some parameters in a single aggregate.

In the model, aggregates are described as porous spheres in which $\mathrm{bSiO}_{2}$ is homogeneously distributed. As fractal particles, a homogeneous distribution of the $\mathrm{bSiO}_{2}$ in aggregates seems to be a reasonable assumption. We chose to represent only the impact of dSi concentrations, adsorption processes and diatom viability on $\mathrm{bSiO}_{2}$ dissolution, but our results showed that they are not the only parameters impacting $\mathrm{bSiO}_{2}$ dissolution in diatom aggregates. At least $60 \%$ of the decrease in the $\mathrm{bSiO}_{2}$ dissolution rate constants measured in aggregates remain unexplained by the model. Other explanations may be suggested from the literature to elucidate the slowdown of the $\mathrm{bSiO}_{2}$ dissolution inside aggregates. First, the aggregate matrix is only considered in the model through porosity, which does not change $\mathrm{bSiO}_{2}$ dissolution. This 
matrix, often identified as TEP, consists of a complex pool of organic ligands. TEP composition varies depending on their origin (bacterial or phytoplankton species) as described in the studies by Bhaskar et al. (2005) and $\mathrm{Xu}$ et al. (2011). Among the molecules identified in these studies, uronic acids (Welch \& Vandevivere 1994) or some exopolymeric saccharides known to be TEP precursors (Penna et al. 2003) directly impacted $\mathrm{bSiO}_{2}$ dissolution, sometimes favouring dissolution and sometimes protecting the $\mathrm{bSiO}_{2}$ against dissolution. The direct impact of the aggregate matrix of the Si cycling remains to be identified before being integrated in the model. The aggregate matrix also contains living organisms, in particular bacteria, which are known to change $\mathrm{bSiO}_{2}$ dissolution. The interaction between organic carbon and $\mathrm{bSiO}_{2}$ at the surface and in the diatom frustule implies that bacterial activity directly impacts $\mathrm{bSiO}_{2}$ dissolution (Patrick \& Holding 1985, Bidle \& Azam 1999, Moriceau et al. 2009). The bacterial community could be both different in aggregates versus free cells (DeLong et al. 1993) and more active in aggregates than in freely suspended cells (Simon et al. 1990). In our experiments, bacteria were highly concentrated compared to most in situ conditions, and bacterial concentrations were typical from non-growing batch cultures. Bacteria were slightly less abundant on aggregates than in freely suspended cells as found for freshly formed diatom aggregates in a study by Simon et al. (1990), which is in accordance with the slow $\mathrm{bSiO}_{2}$ dissolution. However, measurements of activity are needed to resolve this matter.

The chemical and biological composition of the particles forming the aggregate matrix may change $\mathrm{bSiO}_{2}$ dissolution. The chemistry of the seawater 'trapped' in the aggregate porewater changes considerably compared to the surrounding seawater. Not only are nutrient concentrations different, but also oxygen concentrations (Ploug 2001) and pH (e.g. Alldredge \& Cohen 1987). The high bacterial activity in aggregates (Smith et al. 1992, Ziervogel \& Arnosti 2008) and in general the high respiration rates (Iversen \& Ploug 2010) may provoke a decrease in the intra-aggregate $\mathrm{pH}$. Indeed, $\mathrm{pH}$ values around 7 have been measured inside aggregates. A drop in $\mathrm{pH}$ from 8 to 7 could explain a decrease in the dissolution rate by a factor of 2 (measured for Cyclotella cryptica by Greenwood et al. 2001).

Before placing our results in a more general context, we also need to discuss the differences between laboratory-made and in situ aggregates. While aggregates could provide a microhabitat favouring the survival of diatoms in the dark, their viability in natu- ral aggregates that could be largely composed of detritus may be lower than in our laboratory-made aggregates. In an extreme case where aggregated diatoms would all be dead, our results suggest that the $\mathrm{bSiO}_{2}$ dissolution in aggregates could still be lowered by $60 \%$ compared to freely suspended cells. Aggregates in natural environments have a more complex composition than our monospecific aggregates. They may include faecal pellets, algae of many species, bacteria, microzooplankton or larvacean houses. Most of this biological complexity has no impact on $\mathrm{bSiO}_{2}$ dissolution or dSi transport. However, $\mathrm{bSiO}_{2}$ inside faecal pellets tends to dissolve even more slowly (Jansen 2002), and conversely, the impact of microzooplankton grazing, though largely unknown, seems to increase recycling (Ragueneau et al. 2006, Schultes et al. 2010). Among the other biological processes possibly impacting the Si cycle in aggregates, resting spore formation could occur in the dSi-rich microenvironment formed by the aggregates (Alldredge et al. 1995). Their dSi consumption vs. a highly silicified cell wall could contribute to lower the apparent dissolution rate of natural aggregates even more compared to our laboratory-made aggregates that contain no spores. Overall, it appears that in situ, $\mathrm{bSiO}_{2}$ incorporated in aggregates may dissolve slower than $\mathrm{bSiO}_{2}$ freely suspended in the ocean.

\section{Implications for the global Si cycle}

The model predicts that a large fraction of $\mathrm{dSi}$ within aggregates (on the order of $80 \%$ ) is adsorbed to the aggregate matrix, rather than present as free $\mathrm{dSi}$ in the pore solution (using parameters described in Table 2). Adsorption is a reversible process. The ratio between adsorbed and free $\mathrm{dSi}$ is constant and equal to the adsorption constant. The adsorbed $\mathrm{dSi}$ is continuously desorbed or adsorbed as free dSi concentrations decrease or increase to maintain the equilibrium represented by the adsorption coefficient. Diffusion rate depends on the dSi gradient between the outside and the inside of the aggregate. In other words, when dSi is less concentrated outside the aggregate, $\mathrm{dSi}_{\mathrm{agg}}$ is progressively leaking out of the aggregate. Conversely, the external dSi diffuses from the outside to the centre of the aggregate when the gradient is inverted. In the water column, dSi concentration generally increases with depth. During sinking, the aggregate encounters water layers richer in $\mathrm{dSi}$. Considering only diffusion processes, the aggregate internal dSi concentration will increase during its journey through the water column. Moreover, the 
model estimates an adsorption constant between 2 and 5 that can even be up to 10 from the sensitivity analysis. Diffusion processes will ensure that the adsorbed dSi concentration of the aggregate is 2 to 5 times higher than the outside concentrations (Eq. 7). A rough estimate of the share of dSi to the total silica exported at depth can be forecast from the adsorption coefficient calculated by our model. We used these model-derived values together with average dSi concentrations of the different oceanic layers based on a global box model for the silica cycle (Laruelle et al. 2009). This model represents the water column considering 3 boxes. The surface water from 0 to $100 \mathrm{~m}$ has an average dSi concentration of $5 \mu \mathrm{M}$. The mesopelagic layer from 100 to $1000 \mathrm{~m}$ has a global dSi concentration of $25 \mu \mathrm{M}$, while deep waters below $1000 \mathrm{~m}$ contain an average of $100 \mu \mathrm{M}$ of dSi. Using the range of adsorption constants estimated by the model (2.3-5.3), dSi concentrations inside aggregates in such a theoretical water column would be 12 to $27 \mu \mathrm{M}$ in surface waters, 58 to $132 \mu \mathrm{M}$ in mesopelagic waters and 230 to $530 \mu \mathrm{M}$ in deep waters. If we consider an average aggregate volume as given in Table 1, the predicted downward dSi flux would make up 0.5 to $1.3 \%, 2.5$ to $6.6 \%$ and 9.9 to $26.9 \%$ of the $\mathrm{bSiO}_{2}$ flux in the surface, mesopelagic and deep layers, respectively. For the integrated water column, the fraction of silicic acid flux to total silica flux sinking in aggregates can be up to $21 \%$, which is similar to estimates for the fluxes of dissolved carbon and nitrogen (Carlson et al. 1994, Hansell \& Carlson 1998, Engel et al. 2004, Hopkinson \& Vallino 2005). Our crude calculations reveal that, overall, the export of dSi to the sea floor via sinking aggregates could account for up to 4.3 Tmol of $\mathrm{Si}^{-1}$. Obviously this is a very rough estimate, which ignores disaggregation and grazing and assumes that the flux consists of diatom aggregates only, but it does show that this is a potentially significant component of the marine silica cycle that merits further investigation.

\section{CONCLUSION}

Our modelling experiments propose a process able to reconcile 3 results obtained from independent experimental measurements that could at first sight seem inconsistent. The challenge here was to explain how we could measure a low $\mathrm{bSiO}_{2}$ dissolution rate in a diatom aggregate, a strong accumulation of $\mathrm{dSi}$ in the porewater and a dSi diffusion similar to that measured in seawater. If we consider that in the aggregate porewater, $80 \%$ of the dSi is adsorbed as stated by the model, then we could explain the previous 3 statements. The presence of a pool of adsorbed $\mathrm{dSi}$ in the aggregate matrix decreases the pool of silicic acid available to diffuse out of aggregates, which explains why the diffusion coefficient is not decreased. However, adsorption processes would not contribute to lower the biogenic silica dissolution of the frustules embedded in aggregates. Aggregates form a microhabitat promoting the survival of diatoms, which can explain one-third of the effective decrease in the $\mathrm{bSiO}_{2}$ dissolution rate in aggregates. Other factors that still need to be identified may additionally impact dissolution rates within aggregates, including diminished internal $\mathrm{pH}$, bacterial concentration or exopolymeric substances.

If the adsorption constant calculated here is extrapolated to the global ocean, the dissolved component of the Si export could reach up to $20 \%$ of the total Si. Aggregates have been known to play an essential role for the vertical transport of particulate silica in the oceans and thus for the cycling of silica. If adsorption processes are indeed occurring inside aggregates, this raises the possibility that aggregation also plays a role in transporting dissolved silica, which could be important to the oceanic Si cycle.

Acknowledgements. We thank S. Ni Longphuirt and M. Garvey, who kindly read earlier versions of this manuscript, and J. Thebault for his help with the figures. We are sincecerely grateful to the reviewers and the editor for their insightful comments that helped to considerably improve this manuscript. We acknowledge funding to B.M. from the EU, partly through the ORFOIS (EVK2-CT2001-00100) project and partly through the Si-WEBS (HPRN-CT-200200218) Research Training network of the Marie Curie programme, and funding to U.P. from the National Science Foundation (NSF). This research was also partly funded by King Abdullah University of Science and Technology (KAUST) Center-in-Development Award to Utrecht University (project No. KUK-C1-017-12).

\section{LITERATURE CITED}

Alldredge AL, Cohen Y (1987) Can microscale chemical patches persist in the sea? Microbial study of marine snow, faecal pellets. Science 235:689-691

Alldredge AL, Gotschalk C (1988) In situ settling behaviour of marine snow. Limnol Oceanogr 33:339-351

Alldredge AL, Gotschalk C, Passow U, Riebesell U (1995) Mass aggregation of diatom blooms: insights from a mesocosm study. Deep-Sea Res II 42:9-27

Aller RC (1983) The importance of the diffusive permeability of animal burrow linings in determining marine sediment chemistry. J Mar Res 41:299-322

Aller RC, Aller JY (1998) The effect of biogenic irrigation intensity and solute exchange on diagenetic reaction rates in marine sediments. J Mar Res 56:905-936 
Armstrong RA, Lee C, Hedges JI, Honjo S, Wakeham SG (2002) A new, mechanistic model for organic carbon fluxes in the ocean based on the quantitative association of POC with ballast minerals. Deep-Sea Res II 49:219-236

Armstrong RA, Peterson ML, Lee C, Wakeham SG (2009) Settling velocity spectra and the ballast ratio hypothesis. Deep-Sea Res II 56:1470-1478

- Bennett PC (1991) Quartz dissolution in organic aqueous systems. Geochim Cosmochim Acta 55:1781-1797

> Benning LG, Phoenix VR, Yee N, Tobin MJ (2004) Molecular characterization of cyanobacterial silicification using synchrotron infrared micro-spectroscopy. Geochim Cosmochim Acta 68:729-741

Berner RA (1980) Early diagenesis. A theoretical approach. Princeton University Press, Princeton, NJ

> Bhaskar PV, Grossart HP, Bhosle NB, Simon M (2005) Production of macroaggregates from dissolved exopolymeric substances (EPS) of bacterial and diatom origin. FEMS Microbiol Ecol 53:255-264

Bidle KD, Azam F (1999) Accelerated dissolution of diatom silica by marine bacterial assemblages. Nature 397: 508-512

> Billett DSM, Lampitt RS, Rice AL, Mantoura RFC (1983) Seasonal sedimentation of phytoplankton to the deep-sea benthos. Nature 302:520-522

Booth BC, Larouche P, Bélanger S, Klein B, Amiel D, Mei ZP (2002) Dynamics of Chaetoceros socialis blooms in North Water. Deep-Sea Res II 49:5003-5025

Boudreau BP (1997) Diagenetic models and their implementation: modelling transport and reactions in aquatic sediments. Springer-Verlag, Berlin

Boudreau BP, Jørgensen BB (2001) The benthic boundary layer: transport processes and biogeochemistry. Oxford University Press, New York, NY

Brzezinski MA, Alldredge AL, O'Bryan LM (1997) Silica cycling within marine snow. Limnol Oceanogr 42: 1706-1713

> Buesseler KO (1998) The decoupling of production and particulate export in the surface ocean. Global Biogeochem Cycles 12:297-310

> Carlson CA, Ducklow HW, Michaels AF (1994) Annual flux of dissolved organic carbon from the euphotic zone in the northwestern Sargasso Sea. Nature 371:405-408

Carlson CA, Ducklow HW, Hansell DA, Smith WO Jr (1998) Organic carbon partitioning during spring phytoplankton blooms in the Ross Sea polynya and the Sargasso Sea. Limnol Oceanogr 43:373-386

Cussler EL (1984) Diffusion: mass transfer in fluid systems. Cambridge University Press, Cambridge

De La Rocha CL, Nowald N, Passow U (2008) Interactions between diatoms, minerals, POC, and DOM: further implications for the ballast hypothesis. Glob Biogeochem Cycles 22:GB4005, doi:10.1029/2007GB003156

DeLong EF, Franks DG, Alldredge AL (1993) Phylogenetic diversity of aggregate-attached vs. free-living marine bacterial assemblages. Limnol Oceanogr 38:924-934

Deschatre M, Lescop B, Simon Colin C, Ghillebaert F, Guezennec J, Rioual S (2014) Characterization of exopolysaccharides after sorption of silver ions in aqueous solution. J Environ Chem Engineer, doi:10.1016/j.jece. 2014.09.021

Engel A, Thoms S, Riebesell U, Rochelle-Newall E, Zondervan I (2004) Polysaccharide aggregation as a potential sink of marine dissolved organic carbon. Nature 428: 929-932
Frampton MB, Zelisko PM (2009) Organosilicon biotechnology. Silicon 1:147-163

Garvey M, Moriceau B, Passow U (2007) Applicability of the FDA assay to determine the viability of marine phytoplankton under different environmental conditions. Mar Ecol Prog Ser 352:17-26

> Gogou A, Repeta DJ (2010) Particulate-dissolved transformations as a sink for semi-labile dissolved organic matter: chemical characterization of high molecular weight dissolved and surface-active organic matter in seawater and in diatom cultures. Mar Chem 121:215-223

> Greenwood J, Truesdale VW, Rendell AR (2001) Biogenic silica dissolution in seawater - in vitro chemical kinetics. Prog Oceanogr 48:1-23

> Guidi L, Stemmann L, Jackson GA, Ibanez F and others (2009) Effects of phytoplankton community on production, size and export of large aggregates: a world-ocean analysis. Limnol Oceanogr 54:1951-1963

> Hansell DA, Carlson CA (1998) Deep-ocean gradients in the concentration of dissolved organic carbon. Nature 395: 263-266

> Hopkinson CS, Vallino JJ (2005) Efficient export of carbon to the deep ocean through dissolved organic matter. Nature 433:142-145

Iler RK (1977) Hydrogen-bonded complexes of silica with organic compounds. In: Bendz G, Lindquist I (eds) Biogeochemistry of silicon and related problems. Plenum, New York, NY, p 53-76

Iversen MH, Ploug H (2010) Ballast minerals and the sinking carbon flux in the ocean: carbon-specific respiration rates and sinking velocities of macroscopic organic aggregates (marine snow). Biogeosci Discuss 7:3335-3364

Jansen S (2002) Silikatlösung von Diatomeen durch Zooplanktonfraß. M Sc thesis, Universität zu Köln, Cologne

Kemp AES, Pike J, Pearce RB, Lange CB (2000) The 'fall dump' - a new perspective on the role of a 'shade flora' in the annual cycle of diatom production and export flux. Deep-Sea Res I 47:2129-2154

Kemp AES, Pearce RB, Grigorov I, Rance J, Lange CB, Quilty P, Salter I (2006) The production of giant marine diatoms and their export at oceanic frontal zones: implications for $\mathrm{Si}$ and $\mathrm{C}$ flux in stratified oceans. Glob Biogeochem Cycles 20:GB4S04, doi:10.1029/2006GB002698

> Laruelle GG, Roubeix V, Sferratore A, Brodhern B and others (2009) The global biogeochemical cycle of silicon: role of the land-ocean transition and response to anthropogenic perturbation. Glob Biogeochem Cycles 23: GB4031, doi:10.1029/2008GB003267

Mann DG (1999) The species concept in diatoms. Phycologia 38:437-495

Moriceau B, Gallinari M, Soetaert K, Ragueneau O (2007a) Importance of particle formation to reconstructed water column biogenic silica fluxes. Glob Biogeochem Cycles 21:GB3012, doi:10.1029/2006GB002814

> Moriceau B, Garvey M, Ragueneau O, Passow U (2007b) Evidence for reduced biogenic silica dissolution rates in diatom aggregates. Mar Ecol Prog Ser 333:129-142

- Moriceau B, Goutx M, Guigue C, Lee C and others (2009) $\mathrm{Si}-\mathrm{C}$ interactions during degradation of the diatom Skeletonema marinoi. Deep-Sea Res II 56:1381-1395

Nelson DM, Goering JJ, Kilham SS, Guillard RRL (1976) Kinetics of silicic acid uptake and rates of silica dissolution in the marine diatom Thalassiosira pseudonana. J Phycol 12:246-252 
Nelson DM, Tréguer P, Brzezinski MA, Leynaert A, Quéguiner B (1995) Production and dissolution of biogenic silica in the ocean: revised global estimates, comparison with regional data and relationship to biogenic sedimentation. Global Biogeochem Cycles 9:359-372, doi:10.1029/956B01070

Nielsen AE (1984) Electrolyte crystal growth mechanisms. J Cryst Growth 67:289-310

Passow U (2002) Production of transparent exopolymer particles (TEP) by phyto- and bacterioplankton. Mar Ecol Prog Ser 236:1-12

Passow U, Engel A, Ploug H (2003) The role of aggregation for the dissolution of diatom frustules. FEMS Microbiol Ecol 46:247-255

Passow U, French MA, Robert M (2011) Biological controls on dissolution of diatom frustules during their descent to the deep ocean: lessons learned from controlled laboratory experiments. Deep-Sea Res I Oceanogr Res Pap 58: 1147-1157

Patrick S, Holding AJ (1985) The effect of bacteria on the solubilization of silica in diatom frustules. J Appl Bacteriol 59:7-16

> Penna A, Magnani M, Fenoglio I, Fubini B, Cerrano C, Giovine M, Bavestrello G (2003) Marine diatom growth on different forms of particulate silica: evidence of cell/particle interaction. Aquat Microb Ecol 32:299-306

Peters E, Thomas DN (1996) Prolonged darkness and diatom mortality I: marine Antarctic species. J Exp Mar Biol Ecol 207:25-41

Ploug H (2001) Small-scale oxygen fluxes and remineralization in sinking aggregates. Limnol Oceanogr 46: 1624-1631

Ploug H, Jørgensen BB (1999) A net-jet flow system for mass transfer and microsensor studies of sinking aggregates. Mar Ecol Prog Ser 176:279-290

Ploug H, Passow U (2007) Direct measurement of diffusivity within diatom aggregates containing transparent exopolymer particles. Limnol Oceanogr 52:1-6

Ploug H, Terbrüggen A, Kaufmann A, Wolf-Gladrow D, Passow U (2010) A novel method to measure particle sinking velocity in vitro, and its comparison to three other in vitro methods. Limnol Oceanogr Methods 8:386-393

Ragueneau O, Schultes S, Bidle KD, Claquin P, Moriceau B (2006) Si and C interactions in the world ocean: importance of ecological processes and implications for the role of diatoms in the biological pump. Glob Biogeochem Cycles 20:GB4S02, doi:10.1029/2006GB002688

Rebreanu L, Vanderborght JP, Chou L (2008) The diffusion coefficient of dissolved silica revisited. Mar Chem 112: 230-233

Schultes S, Lambert C, Pondaven P, Corvaisier R, Jansen S, Ragueneau O (2010) Recycling and uptake of $\mathrm{Si}(\mathrm{OH})_{4}$ when protozoan grazers feed on diatoms. Protist 161: 288-303

Editorial responsibility: Katherine Richardson, Copenhagen, Denmark
Shanks AL, Trent JD (1979) Marine snow:microscale nutrient patches. Limnol Oceanogr 24:850-854

Simon M, Alldredge AL, Azam F (1990) Bacterial carbon dynamics on marine snow. Mar Ecol Prog Ser 65:205-211

Smith DC, Simon M, Alldredge AL, Azam F (1992) Intense hydrolytic enzyme activity on marine aggregates and implications for rapid particle dissolution. Nature 359: 139-141

> Stemmann L, Boss E (2012) Plankton and particle size and packaging: from determining optical properties to driving the biological pump. Annu Rev Mar Sci 4:263-290

Tamburini C, Garcin J, Grégori G, Leblanc K, Rimmelin P, Kirchman DL (2006) Pressure effects on surface Mediterranean prokaryotes and biogenic silica dissolution during a diatom sinking experiment. Aquat Microb Ecol 43: 267-276

> Thornton DCO (2002) Diatom aggregation in the sea: mechanisms and ecological implications. Eur J Phycol 37: 149-161

Tréguer PJ, De La Rocha CL (2013) The world ocean silica cycle. Annu Rev Mar Sci 5:477-501

> Tréguer P, Nelson DM, Bennekom AJV, Demaster DJ, Leynaert A, Quéguiner B (1995) The silica balance in the world ocean: a reestimate. Science 268:375-379

> Turner JT (2002) Zooplankton fecal pellets, marine snow and sinking phytoplankton blooms. Aquat Microb Ecol 27:57-102

> Van Cappellen P, Qiu L (1997) Biogenic silica dissolution in sediments of the Southern Ocean. II. Kinetics. Deep-Sea Res II 44:1109-1128

> Van Cappellen P, Dixit S, Van Beusekom J (2002) Biogenic silica dissolution in the oceans: reconciling experimental and field-based dissolution rates. Global Biogeochem Cycles 16:1075

> Verdugo P, Alldredge AL, Azam F, Kirchman DL, Passow U, Santschi PH (2004) The oceanic gel phase: a bridge in the DOM-POM continuum. Mar Chem 92:67-85

> Welch SA, Vandevivere P (1994) Effect of microbial and other naturally occurring polymers on mineral dissolution. Geomicrobiol J 12:227-238

Williams PJL (1995) Evidence for the seasonal accumulation of carbon-rich dissolved organic material, its scale in comparison with changes in particulate material and the consequential effect on net $\mathrm{C} / \mathrm{N}$ assimilation ratios. Mar Chem 51:17-29

Xu C, Zhang S, Chuang C, Miller EJ, Schwehr KA, Santschi $\mathrm{PH}$ (2011) Chemical composition and relative hydrophobicity of microbial exopolymeric substances (EPS) isolated by anion exchange chromatography and their actinide-binding affinities. Mar Chem 126:27-36

Ziervogel K, Arnosti C (2008) Polysaccharide hydrolysis in aggregates and free enzyme activity in aggregate-free seawater from the north-eastern Gulf of Mexico. Environ Microbiol 10:289-299

Submitted: October 17, 2011; Accepted: September 1, 2014 Proofs received from author(s): November 24, 2014 